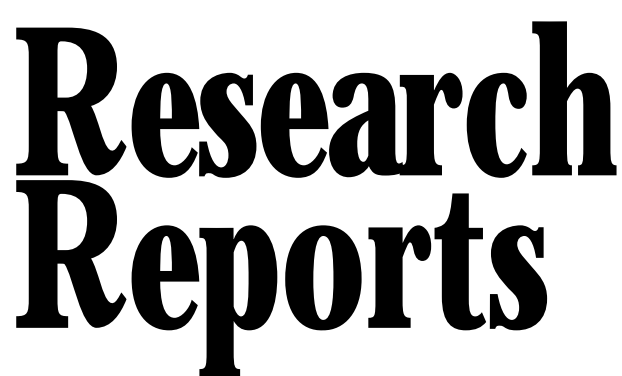

\section{Stratification and Light Improve Germination of Katsura Tree Seed}

\author{
M ichael S. D osmann, ${ }^{1}$ \\ J effery K. Iles, ${ }^{2}$ and \\ M ark P. Widrlechner ${ }^{3}$
}

\section{Additional index words. Cercidiphyllum japonicum, Cerdidiphyllum magnificum, sexual propagation, dormancy, woody landscape plants}

Summary. G erminability of two, halfsib seed sources of Cercidiphyllum japonicum Sieb. \& Z ucc. and one seed source of Cercidiphyllum magnificum ( $\mathrm{N}$ akai) $\mathrm{N}$ akai was determined after

I owa Agriculture and $\mathrm{H}$ ome Economics Experiment Station journal paper J-17848. Supported by $\mathrm{H}$ atch Act and state of I owa funds. We thank the Arnold Arboretum of $\mathrm{H}$ arvard $\mathrm{U}$ niversity (J amaica Plain, $\mathrm{MA}$ ) and the Forest Experimental Station of the Warsaw Agricultural U niversity Arboretum (Rogów, Poland) for providing seeds. Mention of commercial brandname products does not constitute an endorsement of any product by the U SD A-ARS or cooperating agencies. The cost of publishing this paper was defrayed in part by the payment of page charges. Under postal regulations, thispaper thereforemust behereby marked advertisement solely to indicate this fact.

${ }^{1} \mathrm{G}$ raduate research assistant, $\mathrm{D}$ epartment of $\mathrm{H}$ orticulture, I owa State U niversity, Ames, I A 50011-1100; to whom reprint requests should be addressed; e-mail: dosmann@iastate.edu.

${ }^{2}$ Associate professor, D epartment of $\mathrm{H}$ orticulture, I owa State U niversity, Ames, IA 50011-1100.

${ }^{3} \mathrm{H}$ orticulturist, U .S. D epartment of Agriculture-Agricultural Research Service, North Central Regional Plant Introduction Station, I owa State U niversity, D epartments of Agronomy and $\mathrm{H}$ orticulture, Ames, IA 50011-1170. not stratifying or stratifying seeds at $3.5 \pm 0.5^{\circ} \mathrm{C}\left(38.3 \pm 0.9^{\circ} \mathrm{F}\right)$ for 8 days followed by germination for 21 days at $25^{\circ} \mathrm{C}\left(77^{\circ} \mathrm{F}\right)$ in darkness or under a 15-hour photoperiod. Stratification was not required for germination, but increased germination percentage, peak value, and germination value for both species. Stratification increased germination of $C$. japonicum from $42 \%$ to $75 \%$ and germination of $\mathrm{C}$. magnifiaum from $12 \%$ to $24 \%$ Light enhanced germination of nonstratified seeds of one source of $C$. japonicum and of C. magnificum from $34 \%$ to $52 \%$ and from $8 \%$ to $15 \%$, respectively. Stratification improved germinability of both species and obviated any preexisting light requirements the seeds may have had.

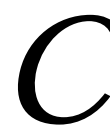

ercidiphyllum comprises two species, both known as katsura tree. The common katsura (C ercidiphyllum japoni cum) is endemic to C hina and J apan, although the survival of the species is threatened in C hina where it has been classified as rare (Chien, 1992). The species is a stunning specimen tree, valued for its pyramidal to broadly spreading form, apricot-yellow autumn leaves, and slightly furrowed bark. The second species, Cercidiphyllum magnificum, has a diminutive range in isolated mountainous regions of Japan and, although it is rare in commercial nurseries, has much potential merit as a landscapetree. Additional information on the genus can be found in recent reviews by Andrews (1998) and Dosmann (1999).

Cercidiphyllum japonicum can be vegetatively propagated by softwood cuttings (D irr and H euser, 1987), but commercial propagation is typically by seed. I nformation about the pretreatment and germination requirements of katsura seedsislimited to a single report that states that the optimal temperature range for seed germination of $C$. japonicum isfrom 21 to $25^{\circ} \mathrm{C}$ (69.8 to $77^{\circ} \mathrm{F}$ ) (Rohde, 1977). While katsura is not regarded asdifficult to propagateby seed, general recommendationsfor seed germination of $C$. japoni cum vary, asdo reports of germination success. Reports on the germination of $\mathrm{C}$. magnificum do not exist.

D irr and $\mathrm{H}$ euser (1987) note that stratification is not required for germination. Yet, for maximum germination, some nurseries sow seeds in spring after stratification for up to $60 \mathrm{~d}$ ( H . Kunkel, personal communication). Seeds sown outdoors immediately after ripening in autumn germinate near capacity the following spring (D. H inkley, personal communication). O ther nurseries have found stratification unnecessaryand sow seed outdoors directly in spring ( $M$. Anderson, personal communication). Conservationistsfrom the Xi'an Botanical Garden, China, reported that sowing seeds of $C$. ja poni cum in fall yielded only $23 \%$ germination, whilespring sowing of stratified seed (temperature and duration not reported) increased germination percentage to $70 \%$ (W Wang et al., 1990).

Effects of light on katsura seed germination are unknown. Seeds are small [ about $5 \mathrm{~mm}$ (0.20 inches) long in C. japonicum and about $6 \mathrm{~mm}(0.24$ inches) long in C. magnificum] with thin seed coats, both characteristics associated with light sensitivity (Bewley and Black, 1982; Li et al., 1994). O ur objectiveswere to determine the effects of stratification and light on seed germination of thetwo species of katsura, and generate information of value for commercial production and conservation efforts, wheresomedifficulty in production has been noted.

\section{Materials and Methods}

Cercidiphyllum japonicum. O n 26 Sept. 1996, ripened follicles were obtained from two open-pollinated trees of $C$. japonicum growing at the Arnold Arboretum of $\mathrm{H}$ arvard $\mathrm{U}$ niv. (Jamaica Plain, $M$ ass.), identified by the accession numbers of the maternal parent trees, 1150-67 and 882. U pon receipt, follicles were dried in shallow trayson a glasshousebench for 3 weeks. After drying, seeds were shaken from their follicles, sealed in airtight plastic containers, and stored in darkness at about $7^{\circ} \mathrm{C}\left(44.6^{\circ} \mathrm{F}\right)$ to maintain dor- 
mancy until the initiation of treatments.

Treatments began on 2 D ec. 1996. Seeds were placed (25/ dish) in $100 \times$ $15 \mathrm{~mm}(3.9 \times 0.6$ inch) plastic petri dishes (Fisherbrand, Pittsburgh, $\mathrm{Pa}$.) on one piece of germination paper (Anchor Paper, H udson, Wis.) moistened with $5 \mathrm{~mL}(0.17 \mathrm{fl} \mathrm{oz})$ of deionized water. Seeds were stratified in darkness at $3.5 \pm 0.5^{\circ} \mathrm{C}\left(38.3 \pm 0.9^{\circ} \mathrm{F}\right)$ for $8 \mathrm{~d}$ in a ScienTemp programmable freezer (ScienTemp Corp., Adrian, M ich.). Temperature and duration of stratification were based on preliminary research that indicated that a short period of stratification was necessary to remove dormancy. Because of thelimited quantity of seeds available, additional stratification treatments were not used. After stratification, nonstratified seeds were placed in dishes in the same manner as the stratified seeds.

Stratified and nonstratified seeds were randomly arranged on the same rack within a Sherer CEL-8 incubator (Conviron, Asheville, N.C.) at $25^{\circ} \mathrm{C}$ ( $77^{\circ} \mathrm{F}$ ) (Rohde, 1977) under a photoperiod of $15 \mathrm{~h}$ or complete darkness. Light was provided by cool-white fluorescent lamps $\left(64 \pm 8 \mu \mathrm{mol} \cdot \mathrm{m}^{-2} \cdot \mathrm{s}^{-1}\right.$ photosyntheticallyactiveradiation measured at dish level with a quantum radiometer [LI-COR, Lincoln, N eb.]), and complete darkness was obtained by placing dishes in light-proof containers. Throughout the study, filter paper was remoistened as needed with deionized water. Dishes in the dark treatment were opened only briefly to remoisten paper and count germinated seeds. The experiment was terminated after $21 \mathrm{~d}$.

Germination percentagewascomputed daily for each dish, and was de- fined as the percentage of seeds that showed radicleemergence, without correction for nonviable seeds. At the conclusion of the experiment, peak and germination values (Czabator, 1962) and final germination percentages were calculated. Peak value is an index of vigor and is obtained by dividing, for each day of measurement, the cumulativegermination percentagebythenumber of days from the beginning of the germination test. The maximum daily value is defined as the peak value. Germination value is the product of peak value and the mean daily germination percentage, which is determined by dividing final germination percentage by the number of days for completion of germination. Germination value combines speed and totality of germination in a single index.

The factorial arrangement for statistical analysis consisted of two seed sources, two stratification treatments (stratified and nonstratified), and two light conditions (light and dark). Each dish of 25 seeds was considered an experimental unit. E ach treatment combination wasreplicated threetimes, and the experiment was conducted three times. D ata were analyzed with the Statistical Analysis System (SAS I nstitute, Cary, N.C.). Analyses of variance, performed with the $G$ eneral $L$ inear $M$ odel (PROC GLM), tested for significance of seed sources, stratification treatments, and light effects for the measured response variables. $\mathrm{H}$ igh-order interactions (replication over time $\times$ seed source $\times$ stratification treatment $\times$ photoperiod $\times$ within treatment replication) were included as a measure of experimental error. M eans were separated by using
Fisher'sleast significant difference (LSD) test at $\mathrm{P} \leq 0.05$.

Cercidiphyllum magnificum. On 16 D ec. 1996, a limited supply of seeds of $C$. magnificum was received from the Forest Experimental Station of theWarsaw Agricultural U niv. Arboretum (Rogów, Poland). The seeds had been collected from four open-pollinated female trees during the first half of September 1996, dried, and stored in unsealed containersat -3 to $10^{\circ} \mathrm{C}$ ( 26.6 to $\left.50^{\circ} \mathrm{F}\right)$. U pon receipt, seeds were resealed in plastic containers and held at about $7{ }^{\circ} \mathrm{C}\left(44.6^{\circ} \mathrm{F}\right)$.

Tests similar to those for $C$. japonicum were initiated on $5 \mathrm{M}$ ar. 1997, except that a fourth replication over time was added. Experimental error during analysis of variance included the interaction of replication over time $\times$ stratification treatment $\times$ photoperiod $\times$ within treatment replication.

\section{Results}

Cercidiphyllum japonicum. Germination was complete for all treatments 7 to $11 \mathrm{~d}$ after placing seedsin the incubator. $\mathrm{N}$ o further germination was observed, despite continued observation. Germination percentage, peak value, and germination value differed between trees $(P>F=0.0001)$. A tree $\times$ stratification treatment interaction was significant for germination percentage, peak value, and germination value $(P>$ $\mathrm{F}=0.0001$ ). For all three variables, stratification increased germination in tree 1150-67 more than in tree 882 (Table1). Germination percentage, peak value, and germination value for tree 1150-67 were unaffected by photoperiod. H owever, germination percent-

Table 1. M ean germination percentage, peak value, and germination value of seeds of $C$ ercidiphyllum japonicum (sources 1150-67 and 882) and C. magnificum nonstratified or stratified at $3.5 \pm 0.5{ }^{\circ} \mathrm{C}\left(38.3 \pm 0.9{ }^{\circ} \mathrm{F}\right)$ for $8 \mathrm{~d}$ and germinated under complete darkness or $15 \mathrm{~h}$ photoperiod. Values for $\mathrm{C}$. japonicum and C. magnificum are the means of nine or 12 replications, respectively, each consisting of 25 seeds.

\begin{tabular}{|c|c|c|c|c|c|c|c|c|c|c|}
\hline \multirow[b]{4}{*}{$\begin{array}{l}\text { Pregermination } \\
\text { treatment }\end{array}$} & \multirow{4}{*}{$\underset{\text { Photoperiod }}{\text { (h) }}$} & \multicolumn{6}{|c|}{ Seed source } & \multirow{2}{*}{\multicolumn{3}{|c|}{ C. magnificum }} \\
\hline & & \multicolumn{6}{|c|}{ C. japonicum (accession no.) } & & & \\
\hline & & $1150-67$ & 882 & $1150-67$ & 882 & $1150-67$ & 882 & \multirow[b]{2}{*}{$\begin{array}{c}\text { Germination } \\
\%\end{array}$} & \multirow[b]{2}{*}{$\begin{array}{l}\text { Peak } \\
\text { value }\end{array}$} & \multirow[b]{2}{*}{$\begin{array}{c}\begin{array}{c}\text { Germination } \\
\text { value }\end{array} \\
\end{array}$} \\
\hline & & \multicolumn{2}{|c|}{$\underset{\%^{2}}{G}$} & \multicolumn{2}{|c|}{$\begin{array}{c}\text { Peak } \\
\text { value }^{y}\end{array}$} & \multicolumn{2}{|c|}{$\begin{array}{c}\text { G ermination } \\
\text { value }^{x}\end{array}$} & & & \\
\hline \multirow[t]{2}{*}{ N onstratified } & 0 & 39 & 34 & 6.7 & 6.2 & 42 & 33 & 8 & 1.4 & 2.1 \\
\hline & 15 & 42 & 52 & 7.3 & 9.2 & 50 & 71 & 15 & 2.0 & 3.7 \\
\hline \multirow[t]{2}{*}{ Stratified } & 0 & 90 & 60 & 19.5 & 13.2 & 294 & 138 & 23 & 4.3 & 18.5 \\
\hline & 15 & 89 & 59 & 18.8 & 13.0 & 285 & 128 & 24 & 4.5 & 18.6 \\
\hline LSD $^{w}$ & & \multicolumn{2}{|c|}{10} & \multicolumn{2}{|c|}{2.3} & \multicolumn{2}{|c|}{47} & 5 & 0.9 & 6.2 \\
\hline
\end{tabular}

zPercentage of seeds showing radicle emergence without correction for nonviable seeds.

yU nitless index of vigor; maximum daily value obtained by dividing cumulative germination percent by cumulative number of days of germination.

$\times U$ nitless indication of speed and totality of germination; product of peak value and mean daily germination percentage.

${ }^{{ }^{W}}$ Fisher's least significant difference (LSD) within each dependent variable is at $P \leq 0.05$. 
age and peak value were greater for nonstratified seeds of tree 882 exposed to light than those germinated in darkness. The same interaction was not significant for germination value. Light caused no significant differences in any of the response variables for stratified seeds of tree 882 (Table 1 ).

Cercidiphyllum magnific um. Germination was complete in 8 to $11 \mathrm{~d}$. Similar to $C$. japonicum, stratification increased germination percentage, peak value, and germination value $(P>F=$ $0.0001)$. G ermination percentages and peak values for stratified seeds were more than two and three times greater, respectively, than thosefor nonstratified seeds germinated in darkness (Table 1). Germination value for stratified seeds was more than eight times that for nonstratified seeds germinated in darkness. Germination percentage for nonstratified seedsincreased under light, but peak value and germination value for the nonstratified treatments were not different. Stratified seedswere unaffected by light (T able 1).

\section{Discussion}

Stratification was not required for germination of either Cercidiphyllum species, but stratifying seeds increased germination percentage, peak value, and germination value for both. Likewise, light was not required for germination, yet germination percentage for nonstratified seeds of $C$. magnificum, and germination percentage and peak value for nonstratified seeds of tree 882 of $C$. japonicum increased when exposed to light.

In asimilar study, neither stratification nor light was required for germination of seeds of empress tree [Paulownia tomentosa (Thunb.) Steud.], but continuousirradiance improved germination of nonstratified seedswhen compared with seeds germinated in darkness(Carpenter and Smith, 1981). While our study did not examine the effects of continuous light, we observed similar responses in tree 882 of $C$. japonicum and in $\mathrm{C}$. magnificum. Furthermore, when seeds of empress tree were stratified for 2 weeksat $4{ }^{\circ} \mathrm{C}\left(39.2^{\circ} \mathrm{F}\right)$, higher (and equal) germination percentages were observed in both light and dark than those that had not been stratified, indicating that light requirements had been removed by stratification ( $\mathrm{C}$ arpenter and Smith, 1981). In our study, germination speed (peak value) in both species increased after stratification and under light in nonstratified seeds of $C$. japonicum (tree 882). Germination value was unaffected by light, yet was increased by about $530 \%, 156 \%$ and $540 \%$ in trees $1150-67$ and 882 of $C$. japonicum, and $\mathrm{C}$. magnificum, respectively, with stratification. This discovery suggests stratification is more important than light in seed germination of katsura. Similar responses to stratification and irradiance have been observed in downy birch (Betula pubescensE hrh.) (Black and Wareing, 1955), canadian hemlock [T suga canadensis (L.) Carr.] (Stearnsand O Isen, 1958), and longleaf pine (PinuspalustrisM ill.) (M CLemore and $\mathrm{H}$ ansbrough, 1970).

Thedissimilar responsesto stratification and light demonstrated by the two sources of $C$. japonicum in our study are difficult to explain. Differences may have been due to unique circumstances of the two parent trees at theArnold Arboretum, including provenance or microclimate (Bewley and Black, 1982). Seed maturity and physiological status of the two sources also may account for the differences in seed performance. For these and other reasons, we emphasize that our results are based on only two individuals of $C$. japonicum and may not represent the characteristics of the species as a whole. $\mathrm{N}$ evertheless, results from this study may help explain why plant propagators use various methods to produce katsura from seed. Because seeds from individual trees may respond differently to various methodsused to overcomedormancy, growers propagating katsura from seed should monitor their seed sources carefully to maximize germination.

Germination percentages less than $25 \%$ emphasize the need for further study of $\mathrm{C}$. magnificum. Because the parental trees of this species were openpollinated, the possibility that crosspollination occurred between this speciesand nearby $C$. japoni cum cannot be ruled out, although to date, hybridization of the two taxa has not been observed. Futureinvestigationswith alarger number of sources of known provenance may help characterize the variability associated with geographic origin of both taxa.

Propagators that germinate seeds of katsuramay find it beneficial to stratify seeds for a short period of time to improve germination. While our study did not test the effect of overwintering, seedsmay have their dormancy requirements removed by sowing them in the field in the autumn. Exposing the seeds to light isnot necessary for germination, and does not improve germinability of stratified seeds.

\section{Literature Cited}

Andrews, S. 1998. Tree of the year: Cercidiphyllum japonicum. Intl. Dendrol. Soc. Yrbk. 1997: 17-46.

Bewley, J.D. and M. Black. 1982. Physiology and biochemistry of seeds in relation to germination. vol. 2. Viability, dormancy, and environmental control. Springer-Verlag, Berlin.

Black, M . and P.F. Wareing. 1955. Growth studies in woody species. VII: Photoperiodic control of germination in Betula pubescens Ehrh. Physiol. Plant. 8:300-316.

Carpenter, S.B. and N.D. Smith. 1981. Germination of Paulownia seedsin thepres ence and absence of light. USD A For. Serv. Tree Planters' N otes 32:27-29.

Chien, H . 1992. Cercidiphyllum japonicum Sieb. et Zucc., p. 212-213. In: L. Fu and J. J in (eds.). China plant red data book: Rare and endangered plants. Science Press, N ew York.

Czabator, F.J . 1962. Germination value: An index combining speed and completeness of pineseed germination. For. Sci. 8:386-396.

Dirr, M .A. and C.W. H euser, J r. 1987. The reference manual of woody plant propagation: From seed to tissue culture. Varsity Press, Athens, Ga.

D osmann, M.S. 1999. Katsura: A review of Cercidiphylum in cultivation and in the wild. N ew Plantsman 6:52-62.

Li, X.J ., P.J . Burton, and C.L. L eadem. 1994. Interactive effects of light and stratification on the germination of some British Columbia conifers. Can. J. Bot. 72:1635-1646.

M CL emore, B.F . and T. H ansbrough. 1970. Influence of light on germination of Pinus palustrisseeds. Physiol. Plant. 23:1-10.

Rohde, J. 1977. Einfluss der Temperatur auf die Keimung von Cercidiphyllum japonicum. D eutsche Baumschule. 29:176.

Stearns, F. and J. O Isen. 1958. Interactions of photoperiod and temperature affecting seed germination in T suga canadens s A mer. J. Bot. 45:53-58.

Wang, S., P. Zhou, X. Liu, and Q. Liu. 1990. Ex situ and in situ conservation research on rare and endangered plants in Shaanxi, p. 137-147. In: S. H e, Y. Yuan, Y. Gu, H. Q in, D. Xu and T. Dudley (eds.). Present conservation status of rare and endangered species in Chinese botanical gardens. Jiangsu Sci. Technol. Publishing $\mathrm{H}$ ouse, $\mathrm{N}$ anjing, China. 